\title{
Analysis of Mapping Forest, Settlement, and Rice Field Areas in Konawe Selatan District, Indonesia
}

\author{
Andri Estining Sejati ${ }^{1, *}$ (D), I Gede Purwana Edi Saputra ${ }^{2}$ \\ ${ }^{1}$ Geography Education Study Program, Universitas Sembilanbelas November Kolaka, Jl. \\ Pemuda 339 Kolaka, 93561, Indonesia \\ ${ }^{2}$ Physics Education Study Program, Universitas Sembilanbelas November Kolaka, Jl. Pemuda \\ 339 Kolaka, Kolaka, 93561, Indonesia
}

Received 16 October 2021/Revised 13 November 2021/Accepted 26 November 2021/Published 20 December 2021

\begin{abstract}
The rampant land-use change in Konawe Selatan District and the uncontrolled use leads to disaster and environmental stability effect, consequently, mapping the area function is important for controlling land-use activities to reduce the risk of disaster. Therefore, this study aims to determine the direction, distribution, and effective area of the function of forests, settlements, and rice fields. This study used a regional survey with a quantitative approach. Base map data of administrative, slope class, soil type, rainfall, and land-use obtained from the regional planning agency and SAS Planet were used and analyzed with quantitative descriptive analysis overlayed with scoring. The result showed that the direction of area functions was dominated by limited production forests by $50.05 \%$ while the distribution of protected forest function was spread across 14 sub-districts with limited production forests in all sub-districts, production forests in 17 sub-districts, settlements in 21 sub-districts, and rice fields in 9 sub-districts. Furthermore, the effective area shows that all area functions are accordance with the directions, except for rice fields which took over the function of forest while the effective area controlled by the regional planning shows that all area functions need correction following the regulation of the Minister of Agriculture of Indonesia. Areas which do not accordance with the function need to be evaluated, hence, regional planning is required to be revised by the people's representative in Konawe Selatan.
\end{abstract}

Keywords: Analysis; Forest; Rice field; Settlement; Mapping

\section{Introduction}

Land-use change in Konawe Selatan District is rampant and the uncontrolled use leads to disaster and environmental stability effect. This was backed up by BPS (2020) data showing 77 flood cases and 17 landslide cases which indicated that there are human effects on land usage that does not accordance with its function. Therefore, land-use planning needs to pay serious attention to the regional capacity because changes in conservation areas such

*Corresponding author.

Email address : andriest@usn.ac.id (Andri Estining Sejati) 
as deforestation cause flooding, landslides, and erosion (Appannagari, 2018; Hadmoko et al., 2017; Hamdani et al., 2014; Sejati et al., 2019).

The district has several steep slope areas with hilly morphology, this plays an important role in protecting the surrounding environment as environmental changes. Furthermore, landuse activities in line with land-use functions are important in maintaining environmental stability in the region and surrounding areas because analysis of the function of forest areas, settlements, and rice fields has a positive impact on the environment (Basu, 2017; Setiawan et al., 2013).

The suitability of land use practiced in the district is assessed with regional planning by determining the protected forest areas, limited production forests, permanent production forests, settlements, and rice fields. Determination of areas such as protected forests leads to sustainable development related to regional planning and spatial use as experienced by people in India and Indonesia (Latif, 2014; Shankar, 2012).

The creation of good planning goals is influenced by physical factors which are the receptacle for planning and important in the preparation of settlement land suitability (Sejati et al., 2020) while physical and non-physical data are essential in determining green zones and changes in land use in a region (Li et al., 2016; Suryani, 2019). The decree of the Agriculture Minister Number 837 (1980) states that the direction of land use functions is the basis for determining appropriate and permissible activities by considering the physical factors.

Moreover, determination of the direction of land use functions maintains environmental quality, regional sustainability and maximizes potential use space, consequently, this helps toavoid misuse that damages the environment. Meanwhile, regional planning is defined as an activity that involves spatial planning, space utilization, spatial use control, and use of a clear algorithm (Stewart \& Janssen, 2014; Law Number 26, 2007). Masyhuri (2019) stated that changes in land use without planning and utilization that have a strong basis causes damage to the environment.

Study related to mapping the function of the area with GIS includes Zhou et al. (2019) that tracked reforestation in the Loess Plateau in China after the "Grain for Green" project by integrating PALSAR and Landsat imagery with a map accuracy of 91\%. Also, Hirschmugl et al. (2014) mapped forest degradation due to selective logging through time series analysis in Central Africa with map accuracy above 85\% while Lister et al. (2020) used remote sensing data to improve the efficiency of National Forest Inventories in the United States National Forest Inventory. Another was Ganz et al. (2020) that used a combination of Aerial Images 
and Sentinel-2 satellite data compared to National Forest Inventory Data with an accuracy of $95.21 \%$.

Furthermore, $\mathrm{Xu}$ (2021) mapped the settlements from Landsat and Sentinel Time Series by integrating pixel and object-based methods thereby reaching $90 \%$ of areas in different landscape conditions followed by Herfort et al (2019) mapping human settlements with $80 \%$ accuracy and few volunteer efforts by combining crowdsourcing and deep learning. Mansaray et al. (2017) used Sentinel-1A and Landsat 8 Datasets with accuracy increased by $5.3 \%$ on rice fields in Urban Shanghai, Southeast China while Nguyen et al. (2015) mapped rice seasonality in the Mekong Delta with multi-year Envisat ASAR WSM data with an overall accuracy of $85.3 \%$.

Studies related to mapping the function of areas are focused on forest areas such as Ganz et al. (2020) ; Hirschmugl et al. (2014) ; Lister et al. (2020) ; Zhou et al. (2019) , and settlement areas such as Herfort et al. (2019) ; Xu, (2021) and rice fields such as Mansaray et al. (2017) ; Nguyen et al. (2015) . However, complex forest areas, settlements, and rice fields haven't been examined by previous studies, and all previous research used remote sensing in form of single, double, and multiple data. This study combines remote sensing data from ArcGIS Imagery image and regional planning agency which were reviewed by the Regional Planning. However, the new thing is the complex mapping of forest areas, settlements, and rice fields equipped with an analysis of the actual function of the areas studied with remote sensing and geographic information system data, then reviewed with the Regional Planning at the district.

The geographic information system maps forest areas, rice fields, and settlements in Konawe Selatan District with indicators in the Decree of the Agriculture Minister Number 837 (1980) while area functions were analyzed using spatial analysis capabilities (Amnah, 2016; Mann \& Saultz, 2019; Rika et al., 2016). This study aims to determine the direction, distribution, and effective area of the function of forests, rice fields, and settlements in the district.

\section{Methods}

This study is a regional survey with a quantitative approach and physical data were collected using ArcGIS 10.4.1 software for personal use with license subscription while the map of the study area was in the Konawe Selatan District, Southeast Sulawesi, Indonesia. The distance between Konawe Selatan District Capital and Southeast Sulawesi Capital (Kendari City) is 37.3 Kilometers. Figure 1 shows the map of the study area. 


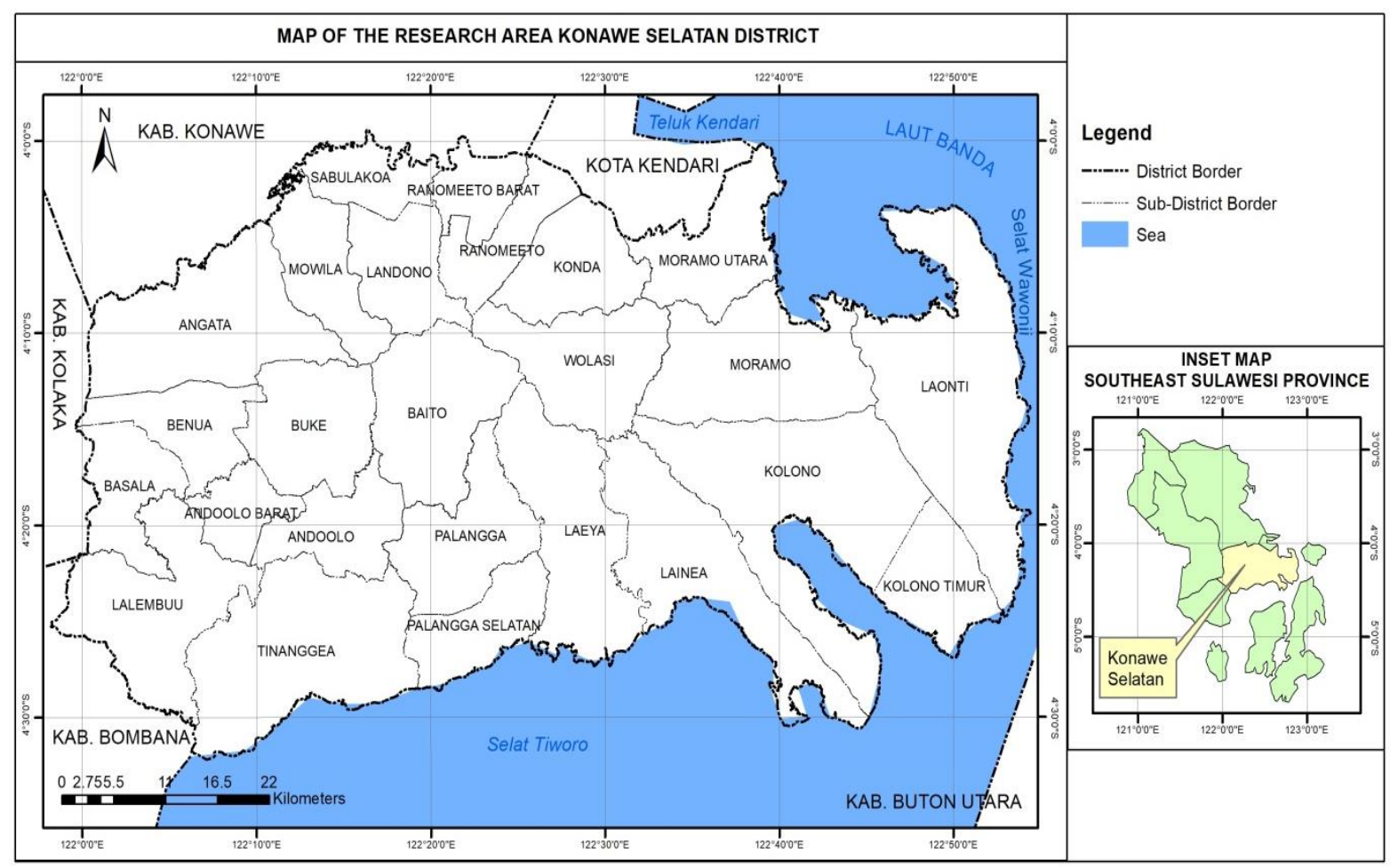

Figure 1. Research Area Konawe Selatan Map

The base map which includes slope map, soil type map, rainfall map were used as physical indicators to determine the area function while the land use map was used to control physical map with actual conditions from ArcGIS Imagery image and the administrative map divided the maps into sub-district to assess the distribution. The slope map, soil type map, rainfall map, and administration map were obtained from the regional planning agency of Konawe Selatan District (BAPPEDA) with a scale of 1:25.000 in 2015 while the land use map was downloaded from the SAS Planet application in form of ArcGIS Imagery Image ECW data with scale 1:25.000 in 2021.

The data were analyzed using quantitative descriptive analysis and was presented as an overlay with scoring equipped with a table of area, area difference, and percentage. The slopes, soil types, and rainfalls map were scored to determine the protected forest area while the map of area function was produced using the overlay method with scoring. Table 1, 2, and 3 shows the scores of each parameter according to the decree of the Agriculture Minister Number 837 in 1980. 
Table 1. Rainfall Scoring

\begin{tabular}{ccc}
\hline Rainfall $(\mathbf{m m} /$ day) & Classification & Score \\
\hline$>34.8$ & Very High & 50 \\
$27.7-34.8$ & High & 40 \\
$20.7-27.7$ & Medium & 30 \\
$13.6-20.7$ & Low & 20 \\
$<13.5$ & Very Low & 10 \\
\hline
\end{tabular}

Table 2. Soil Type Scoring

\begin{tabular}{llc}
\hline \multicolumn{1}{c}{ Soil Type } & \multicolumn{1}{c}{ Classification } & Score \\
\hline Regosol, litosol, organosol, renzina & Very Sensitive & 75 \\
Andosol, laterite, gromosol, podsol, podsolic & Sensitive & 60 \\
Brown forest soil, non calete brown, mediteran & Medium & 45 \\
Latosol & Little Sensitive & 30 \\
Alluvial, glei soil, planosol, brown hydromorf, arterite groundwater & Not Sensitive & 15 \\
\hline
\end{tabular}

Table 3. Slope Scoring

\begin{tabular}{ccc}
\hline Slope $(\%)$ & Classification & Score \\
\hline$>40 \%$ & Flat & 100 \\
$25-40$ & Declivous & 80 \\
$15-25$ & Medium & 60 \\
$8-15$ & Steep & 40 \\
$0-8$ & Very Steep & 20 \\
\hline
\end{tabular}

The criteria for determining forest protection were described in detail in the Decree of the Agriculture Minister Number 837 in 1980. The overlay results of the three score elements were summed and added to the criteria for determining forest area which include a minimum score of 175 or more in protected forest area, score between 125 to 174 in limited production forest area, minimum score of 124 or less in permanent production forest area, minimum score of 124 or less with slope between 2 to $8 \%$ in the rice field area, and minimum score of 124 or less with slope less than $2 \%$ in the settlement area.

The next data obtained was the direction of distribution and percentage and it was overlaid with the administrative map to become a regional distribution map per sub-district while the distribution map was overlaid with land use to become a map of the effective area which was analyzed to obtain the difference between the land use area. The effective area map was evaluated with the suitability of the South Konawe District Spatial Planning by considering the difference. Figure 2 shows the study flow chart. 


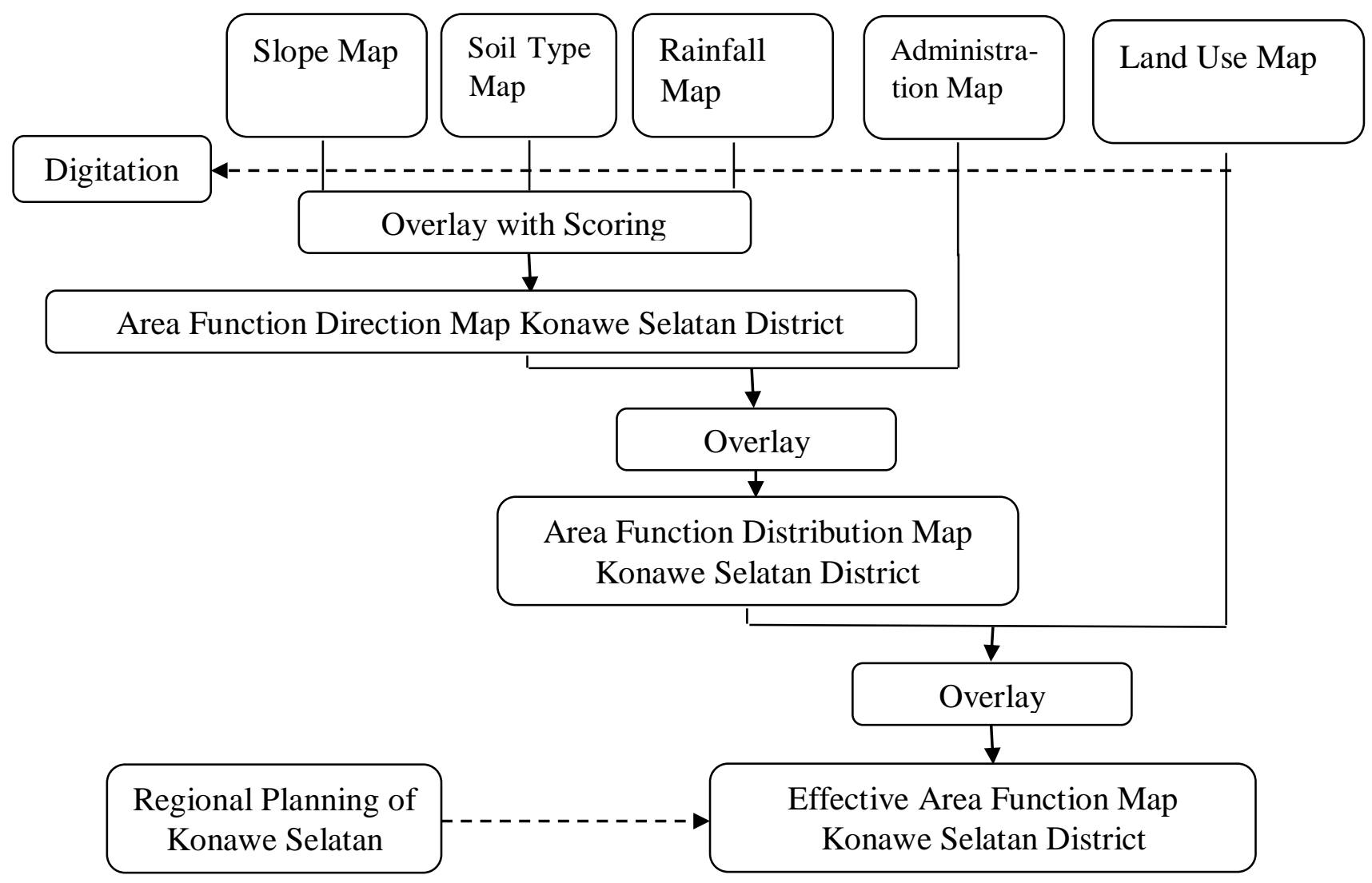

Figure 2. Research flow chart

\section{Results and Discussion}

All rainfalls in Konawe Selatan District are within the score range of 10 with an average annual rainfalls of $1727.029429 \mathrm{~mm}$ and average daily rainfalls of $4.7308571 \mathrm{~mm}$ which ranges between $2.23 \mathrm{~mm} /$ day and $6.33 \mathrm{~mm} /$ day. A score of 10 was obtained because it was included in the daily rainfall range of less than $13.6 \mathrm{~mm}$ which is a very low level or class I. Rainfall was used as a potential component of protected forest with annual data, this is convertible into daily data and given a score according to the parameters specified in the Center for Land Conservation and Soil Conversion (Fitrianti et al., 2013; Wardhana et al., 2020). Figure 3 shows the rainfall map of the Konawe Selatan District. 


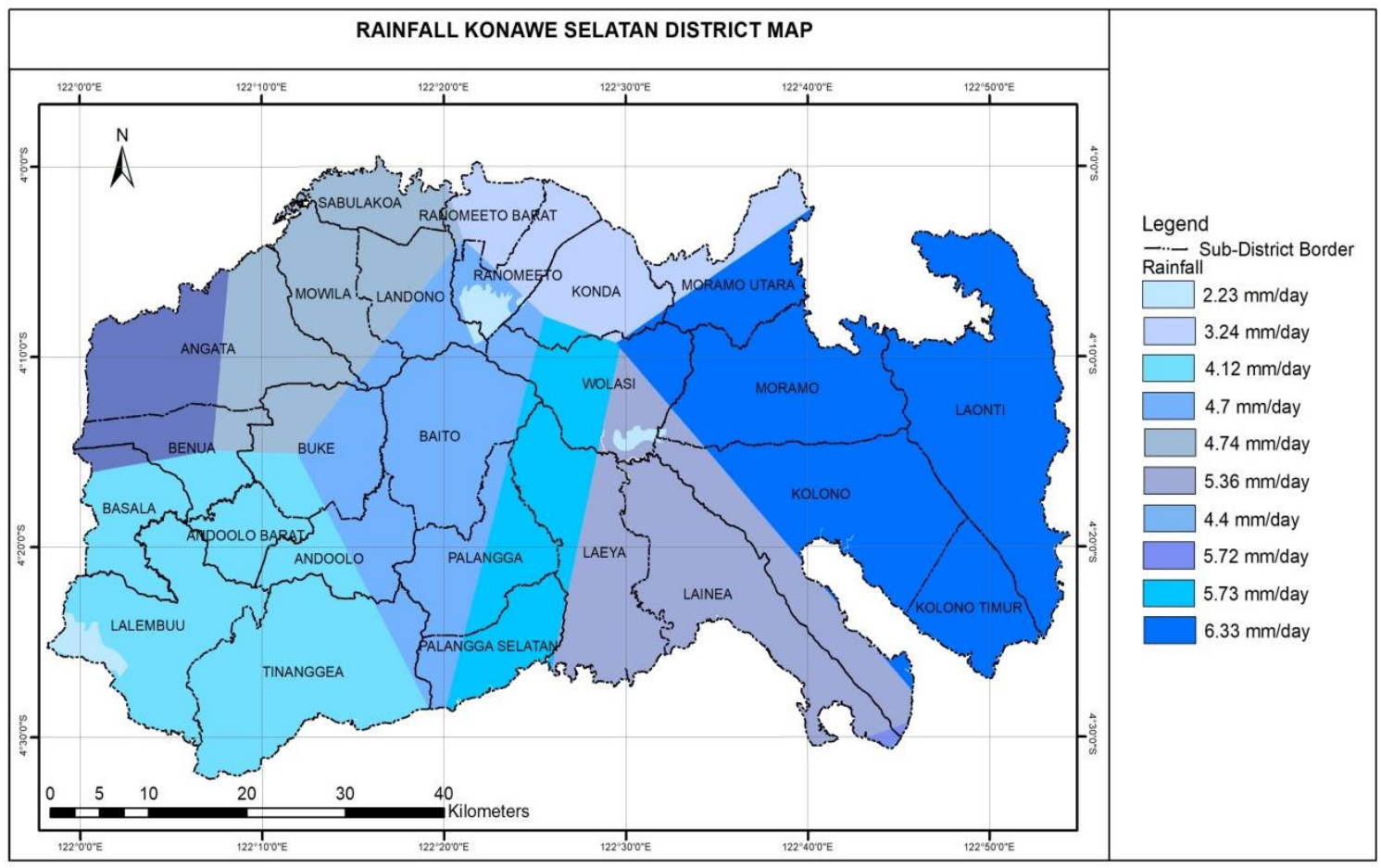

Figure 3. Rainfall map of Konawe Selatan District

The soil type in South Konawe Regency is majorly Podsolik with 193,396.26 hectares or $45.9 \%$, followed by litosol with $100,722.09$ hectares or $23.9 \%$ and kambisol with $72,218.93$ hectares or $17.14 \%$. Soil type scores vary from $15,45,60$, to 75 , and podsolic soils are classified as sensitive to erosion (very high/sensitive or class IV) with a score of 60 while litosol soils are classified as sensitive to erosion (very very high/very sensitive or class V) with a score of 75 . Meanwhile, kambisol soil is classified as high/less sensitive to erosion or class III with a score of 45 . Soil type helps in determining the function of forest areas and shows the level of soil erosion, easily eroded soil has a higher score because the soil needs to be conserved to prevent erosion and disasters such as landslides (Hardianti \& Harudu, 2019; Kurnianto et al., 2018). Figure 4 shows the soil type map of the South Konawe District. 


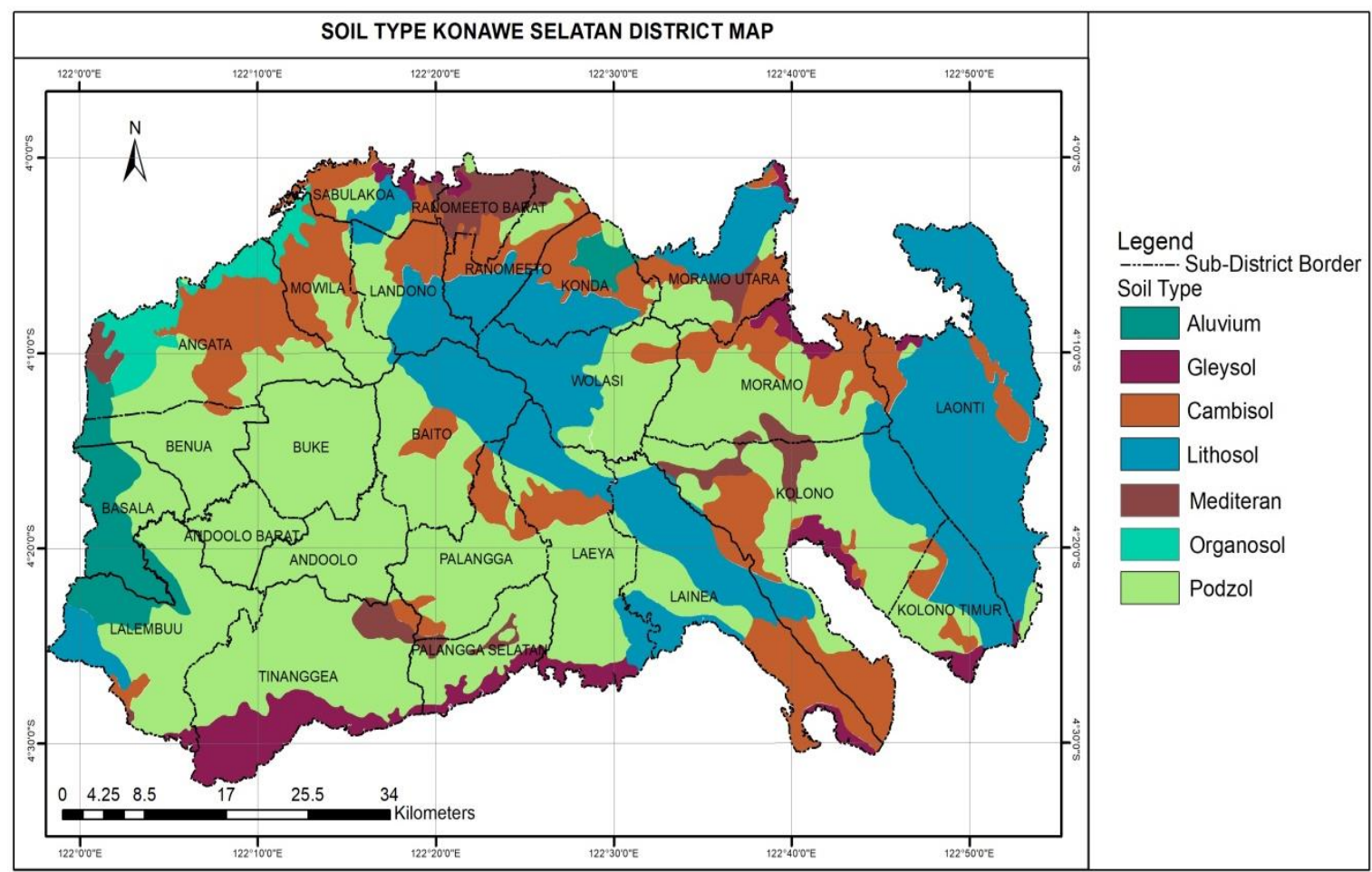

Figure 4. Soil type map of Konawe Selatan District

Furthermore, the district is dominated by slope above $40 \%$ with $149,550.6$ hectares or $35.49 \%$, followed by $0-8 \%$ with $134,386.8$ hectares or $31.89 \%$ and $15-25 \%$ with $123,393.6$ hectares or $29.28 \%$. Soil type scores vary from $20,40,60,80$, to 100 , and slopes above $40 \%$ are classified as very steep or class $\mathrm{V}$ with a score of 100 , slopes of $0-8 \%$ are classified as flat or class I with a score of 20 while slopes of $15-25 \%$ are classified as rather steep or class III with a score of 60 . The gentler the slope, the more suitable it is for residential land use and in this case a maximum of 25\% (Dibyosaputro, 2016; Sakarov, 2019).

The slopes are dominated by the structural karst hills landform with $87.84 \%$, fluviotectonic with $8.93 \%$, and anthropogenic with $3.22 \%$, hence, the most structural karst hill slope is above $40 \%$ with $32.42 \%$. The data shows that Konawe Selatan is hilly karst with various slope which spreads across the sub-district with metamorphic rock created due to faults (Maulana et al., 2018). Meanwhile, the fluvio-tectonic is a landform influenced by rivers and faults that have an energy source from plates in Indonesia (Kusumayudha et al., 2018). The faults in the district are Sangi-Sangi and Konaweha while the anthropogenic are smaller slope areas with activity in the rural settlement (Saadu et al., 2021). Figure 5 shows the slopes map of the South Konawe District. 


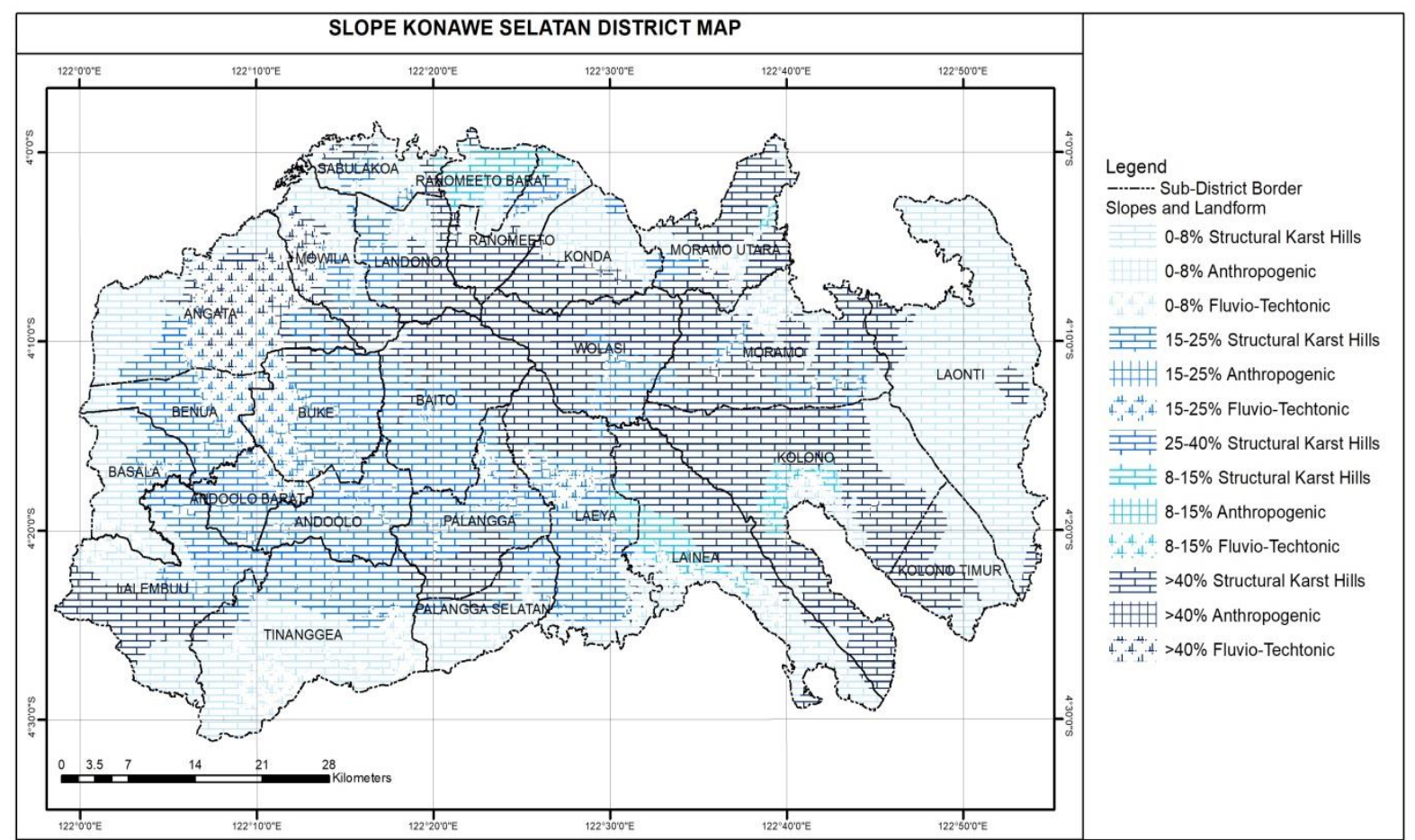

Figure 5. Slope Map of Konawe Selatan District

Rainfall maps, soil types, and slopes of South Konawe District were overlaid to produce a map of the direction of the function of forest areas, rice fields, and settlements with the result of the overlay showing that the direction of the function is dominated by limited production forests with $210,466.7$ hectares or $50.05 \%$ and settlements with $133,899.6$ hectares or $31.84 \%$, then regional potential mapping was used to determine strategic policies in the future (Faturahman, 2017). Table 4 shows the directions of the area function.

Table 4. Direction Area Function of Konawe Selatan Distict

\begin{tabular}{clcc}
\hline Nu. & Direction Area Function & Area (hectares) & Percentage (\%) \\
\hline 1 & Protected forest & 52563.29 & 12.50098 \\
2 & Limited production forest & 210466.7 & 50.05471 \\
3 & Production forest & 9986.818 & 2.375137 \\
4 & Settlement & 133899.6 & 31.84497 \\
5 & Rice Field & 13556.92 & 3.224206 \\
\hline \multicolumn{2}{r}{ Amount } & 420473.3 & 100 \\
\hline
\end{tabular}

Figure 6. shows the area function direction map of Konawe Selatan District. 


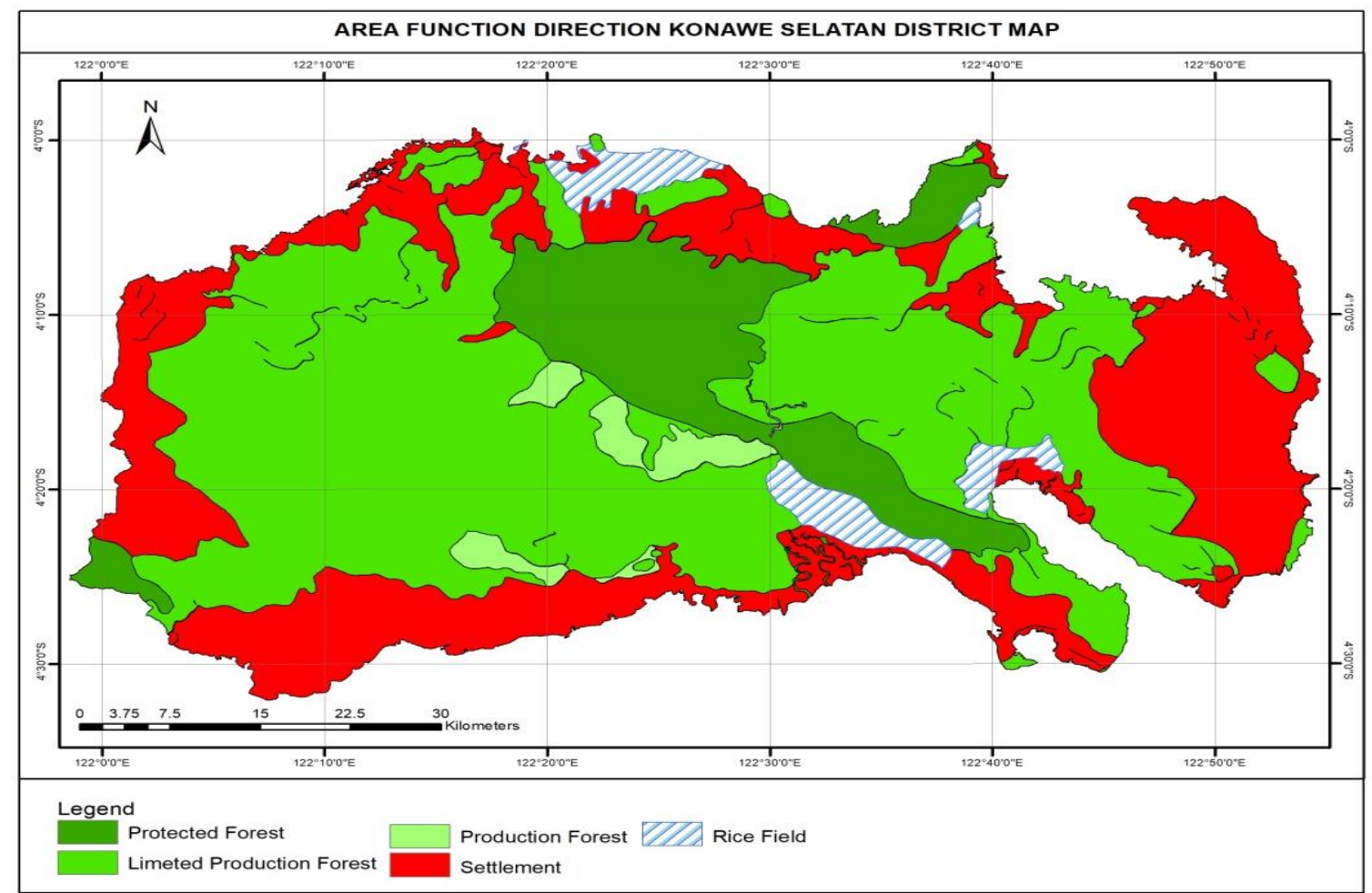

Figure 6. Area function direction map of Konawe Selatan District

The map of the direction of regional functions was overlaid with a map of the subdistrict administration in the area to get a map of the distribution of regional functions. The most protected forest area functions are in Lainea Sub-district with 9,310.68 hectares, Wolasi Sub-district with 8,057.9 hectares, Baito Sub-district with 7,129.75 hectares, Konda Subdistrict with 5,301.83 hectares, Laeya Sub-district with 4,746.84 hectares, Landono Subdistrict with 4,458.04 hectares, Ranomeeto Sub-district with 3,313.46 hectares, Lalembuu Sub-district with 2,648.8 hectares, and Kolono Sub-district with 1,700.37 hectares while other sub-districts have a portion less than 200 hectares. Luxfiati \& Harudu (2019) stated that mapping of forest areas is presentable in form of location distribution and potential suitability with regional planning.

Limited production forests are spread across all sub-districts with Kolono, Moramo, Angata, Buke, Palanga, Lalembuu, Laeya, Andoolo, and Tinanggea having more than 10,000 hectares while other sub-districts have less than 10,000 hectares. However, production forests are spread across 17 sub-districts with Laeya, Palanga, Baito, and Tinanggea sub-districts having more than 1,500 hectares while the other sub-districts have less than 1,500 hectares. According to Lesmana \& Purnama (2017), production forest mapping is useful for 
inventorying production forest locations and assisting the forestry service where the study is carried out.

Settlements are spread over 21 sub-districts having more than 200 hectares, except the Buke sub-district with 12.7 hectares while rice fields are spread over 9 sub-districts with more than 200 hectares in Lainea, Kolono, Laeya, Ranomeeto, North Moramo, West Ranomeeto, and Sabulakoa sub-districts while Landono and North Moramo have less than 200 hectares. Zulfikar et al. (2013) stated that mapping of rice fields to determine the potential increases productivity as well as preventing inappropriate land conversion. Figure 7 shows the area function distribution map.

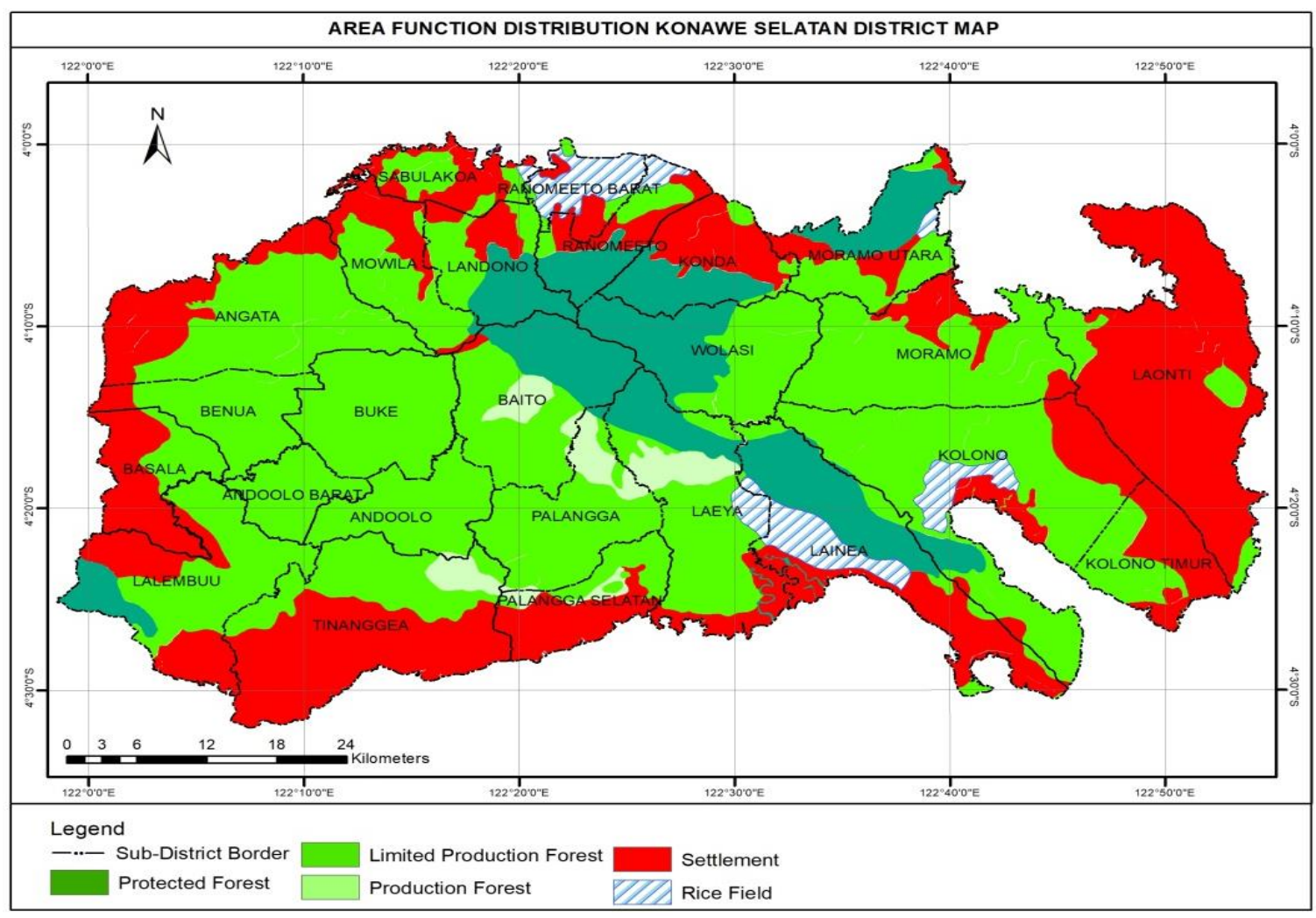

Figure 7. Area function distribution map of Konawe Selatan District

The distribution map is controlled with a land-use map whose base map is based on the ArcGIS Imagery image downloaded from the SAS Planet application to see the actual condition of the first stage. Thereafter, land use map was overlaid with a map of the distribution of area functions to get the corrected effective area and this is a combination of potential through physical base maps obtained from the regional planning agency of South Konawe District in 2015 and the actual situation through SAS Planet images in 2021. David (2016) stated that the ideal mapping of forests in accordance with National Parks is a followup to forest mapping in general while Farizki \& Anurogo (2017) showed that GIS mapping 
and remote sensing images are used as complements. Figure 8 shows the land use map whereas Figure 9 shows the effective area function map in Konawe Selatan District.

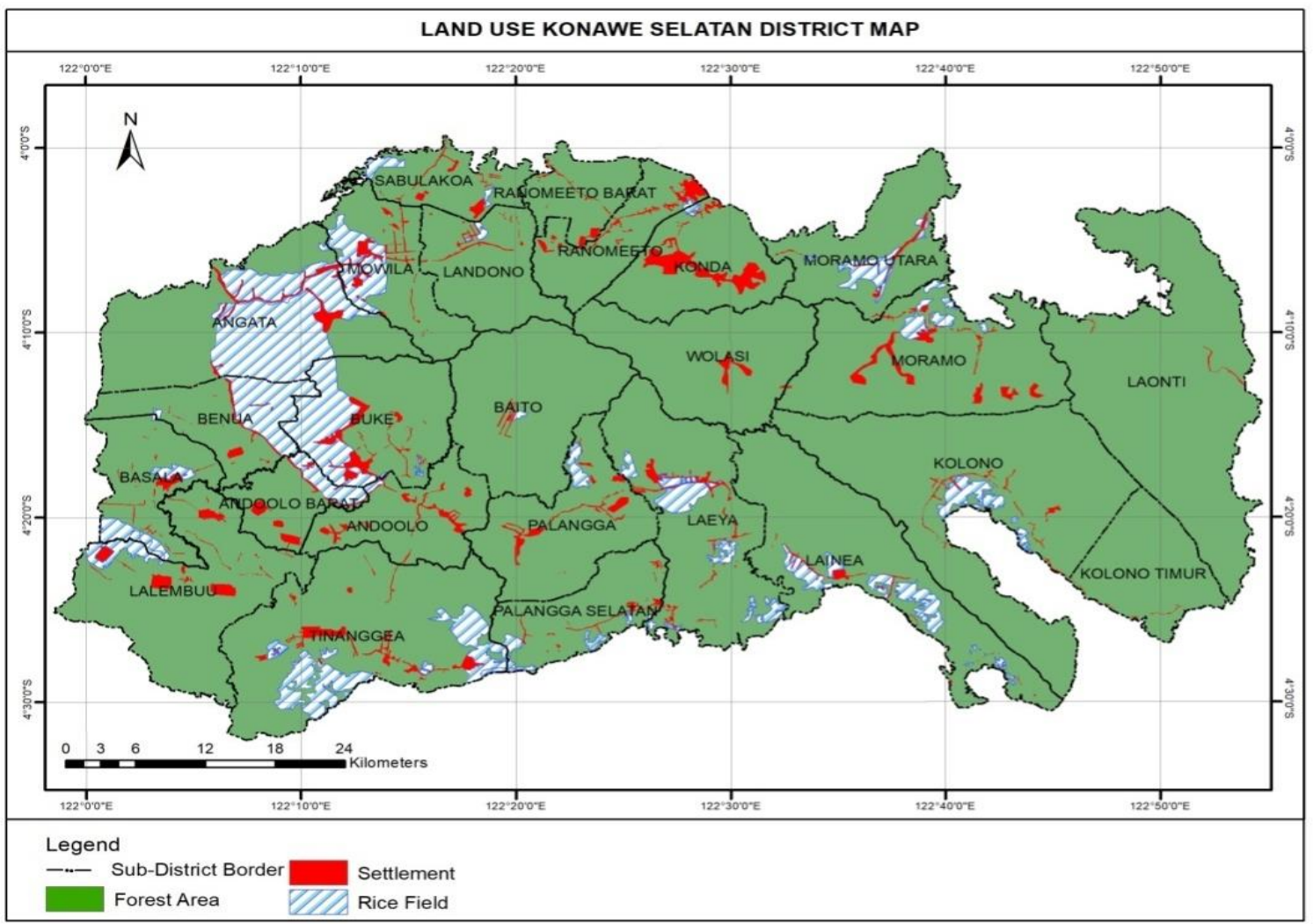

Figure 8. Land use map of Konawe Selatan District

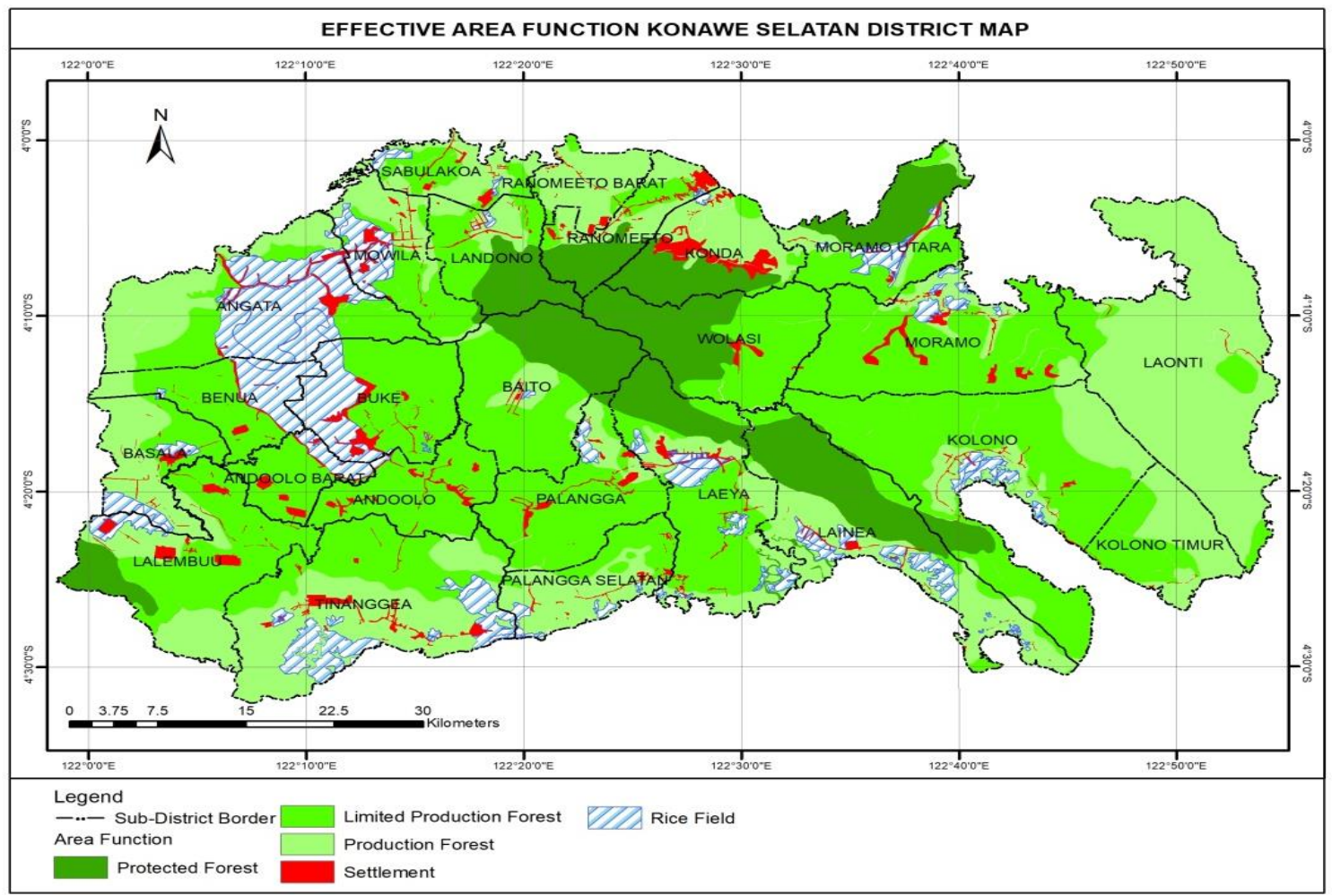

Figure 9. Effective area function map of Konawe Selatan District 
The effective area comparison between land use and direction of the area function (difference 1 in table 5) shows that all the functions of the area accordance with the direction, except the rice field area which exceeds the direction by 35928.33 hectares. The function of the area that has undergone conversion into rice fields is forest area with limited production forest of 30949.22 hectares. A large number of transmigrations is the motive for managing production forest land and limited production forest (Margono et al., 2012).

The effective area controlled by regional planning (difference 2 in Table 5) shows the direction of excess area function in limited production forest with an excess of 175810.47 hectares and rice fields with an excess of 25823.26 hectares of the effective area while the functions of the area which have been converted into limited production forest and rice fields are protected forest area of 69794.78 hectares and production forest of 56886.07 hectares and the protected forest is combined with conservation forest. Meanwhile, the settlements have excess functions of conversion but are still in the reasonable category due to function in regional planning while other village settlements and transmigration are not clearly stated. The real area needs to be controlled with the target area in the regional plan such as the control of slum settlements in Bandung (Maula et al., 2019).

Regional planning as a law at the regional level through Regional Law number 19 in 2013 is controlled by a higher regulation, namely Decree of the Agriculture Minister Number 837 in 1980 as seen in the difference 3 under Table 5. Furthermore, the function of protected and conservation forest areas was corrected by a reduction of 69245.71 hectares, addition of 206759.69 hectares to limited production forest area, reduction of 55030.18 hectares in production forest, addition of 128972.60 hectares to settlements, and reduction of 10105.08 hectares in rice fields. Land use planning involves using the strongest guidelines such as in the Nairobi area that uses Kenya's local agenda 21 planning guide (Panek \& Sobotova, 2015). Table 5 shows the result of the difference analysis between the direction area function based on the ministry of agriculture, effective area based on real land use interpretation of ArcGIS imagery, and the area based on the regional planning. 
Table 5. Area Function Analysis

\begin{tabular}{lcccccc}
\hline \multirow{2}{*}{$\begin{array}{c}\text { Area } \\
\text { Function }\end{array}$} & $\begin{array}{c}\text { Direction } \\
\text { Area } \\
(\mathbf{a})\end{array}$ & $\begin{array}{c}\text { Effective Area } \\
\text { (b) }\end{array}$ & $\begin{array}{c}\text { Regional } \\
\text { planning } \\
(\mathbf{c})\end{array}$ & $\begin{array}{c}\text { Difference 1 } \\
(\mathbf{b}-\mathbf{a})\end{array}$ & $\begin{array}{c}\text { Difference 2 } \\
(\mathbf{b}-\mathbf{c})\end{array}$ & $\begin{array}{c}\text { Difference 3 } \\
(\mathbf{a}-\mathbf{c})\end{array}$ \\
\hline $\begin{array}{l}\text { Protected } \\
\text { forest }\end{array}$ & 52563.29 & 52014.21571 & 121809 & -549.07 & -69794.78 & -69245.71 \\
$\begin{array}{l}\text { Limited } \\
\text { production } \\
\text { forest }\end{array}$ & 210466.69 & 179517.4684 & 3707 & -30949.22 & 175810.47 & 206759.69 \\
$\begin{array}{l}\text { Production } \\
\text { forest }\end{array}$ & 9986.82 & 8130.925599 & 65017 & -1855.89 & -56886.07 & -55030.18 \\
$\begin{array}{l}\text { Settlement } \\
\text { Rice Field }\end{array}$ & 133899.60 & 131325.4436 & 4927 & -2574.15 & 126398.44 & 128972.60 \\
\hline & 13556.92 & 49485.25756 & 23662 & 35928.33 & 25823.26 & -10105.08 \\
\hline
\end{tabular}

\section{Conclusion}

The direction and distribution of area function in the Konawe Selatan District show that all areas have potential functions. The forest area function has the biggest potential and the ability to control the disaster and environmental stability effect. Furthermore, the effective area shows that all area functions accordance with the directions, except for rice fields which led to reduction of the production forest while the area controlled by the regional planning shows the direction of excessive area functions in limited production forests and rice fields which reduced the protected forest area and the production forest. During regional planning of area functions, all functions area needs to be corrected for both addition and reduction following the Regulation of the Minister of Agriculture of the Republic Indonesia. The study on the area of regional planning as a law at the regional level is controlled by a higher regulation like Minister Decree, hence, an advanced study must investigate the suitability between map with actual site condition and regional survey that collects the data from villages in every sub-district.

\section{Conflict of interest}

The authors declare that there is no conflict of interest with any financial, personal, other people or organizations related to the material in this study.

\section{Acknowledgement}

The authors are grateful to Simlitabmas BRIN for providing funding through the National Competitive Research for Beginner Lecturer Research through Decree Number 1867/E4/AK.04/2021 and Accordance ment/Contract Number 053/E4.1/AK.04.PT/2021. 


\section{References}

Amnah. (2016). Rancang bangun sistem informasi geografis penyebaran lokasi hutan lindung pada Provinsi Lampung. Jurnal TIM Darmajaya, 2(1), 63-78.

Appannagari, R. R. (2018). Environmental pollution causes and consequences: a study. North Asian International Research Journal of Social Science \& Humanities, 3(8), $151-161$.

Basu, M. (2017). Fundamentals of Environmental Studies. Mapana - Journal of Sciences, 14(4), 53-56. https://doi.org/10.12723/mjs.35.5.

BPS. (2020). Number of Villages 1 that Had Natural Disaster 2 in the last three years in Sulawesi Tenggara Province by Regency/Municipality. Retrieved from https://sultra.bps.go.id.

David, D. (2016). Sistem informasi geografis pemetaan lokasi ideal taman nasional di Wilayah Kalimantan Barat. Creative Information Technology Journal, 3(3), 242-254. https://doi.org/10.24076/citec.2016v3i3.81.

Dibyosaputro, S. (2016). Landform control on settlement distribution pattern in Progo Delta, Indonesia. Indonesian Journal of Geography, 47(2), 187-193. https://doi.org/10.22146/ijg.9264.

Farizki, M., \& Anurogo, W. (2017). Pemetaan kualitas permukiman dengan menggunakan penginderaan jauh dan SIG di Kecamatan Batam Kota, Batam. Majalah Geografi Indonesia, 31(1), 39-45. https://doi.org/10.22146/mgi.24231.

Faturahman, B. M. (2017). Pemetaan potensi wilayah untuk menunjang kebijakan pangan Kabupaten Pacitan. JISPO Jurnal Ilmu Sosial dan Ilmu Politik, 7(2), 43-62. https://doi.org/10.15575/JP.V7I2.2271.

Fitrianti, F., Sugiyanta, I. G., \& Miswar, D. (2013). Pemetaan arahan fungsi pemanfaatan lahan untuk kawasan fungsi lindung di Kecamatan Gisting Kabupaten Tanggamus. Jurnal Penelitian Geografi, 1(5), 1-5.

Ganz, S., Adler, P., \& Kändler, G. (2020). Forest Cover mapping based on a combination of aerial images and sentinel-2 satellite data compared to national forest inventory data. Forests, 11(12), 1322. https://doi.org/10.3390/F11121322.

Hadmoko, D. S., Lavige, F., Sartohadi, J., Gomez, C., \& Daryono, D. (2017). Spatiotemporal distribution of landslides in java and the trigerring factors. Forum Geografi, 31(1), 1-15. https://doi.org/10.23917/forgeo.v31i1.3790.

Hamdani, H., Permana, S., \& Susetyaningsih, A. (2014). Analisa daerah rawan banjir menggunakan aplikasi sistem informasi geografis (Studi Kasus Pulau Bangka). J Jurnal STT-Garut, 12(1), 1-13. 
Hardianti, A., \& Harudu, L. (2019). Pemetaan persebaran hutan menurut klasifikasi arahan fungsi kawasan hutan di Kabupaten Konawe Selatan berbasis SIG. Jurnal Penelitian Pendidikan Geografi, 4(3), 79-88. https://doi.org/10.36709/jppg.v4i3.8344.

Herfort, B., Li, H., Fendrich, S., Lautenbach, S., \& Zipf, A. (2019). Mapping human settlements with higher accuracy and less volunteer efforts by combining crowdsourcing and deep learning. Remote Sensing, 11(15), 1799. https://doi.org/10.3390/RS11151799.

Hirschmugl, M., Steinegger, M., Gallaun, H., \& Schardt, M. (2014). Mapping forest degradation due to selective logging by means of time series analysis: Case Studies in Central Africa. Remote Sensing, 6(1), 756-775. https://doi.org/10.3390/RS6010756.

Kepmentan-Agriculture Minister Number 837 year 1980. (1980). Surat Keputusan Menteri Pertanian Nomor: 837/Kpts/Um/11/1980 tentang Kriteria dan Tata Cara Penetapan Hutan Lindung. Retrieved from https://mrbudisantoso.files.wordpress.com/2009/02/kriteria-hlhp-keppresmentan.pdf.

Kurnianto, F. A., Apriyanto, B., Nurdin, E. A., Ikhsan, F. A., \& Fauzi, R. B. (2018). Geographic information system (GIS) application to analyze landslide prone disaster zone in Jember Regency East Java. Geosfera Indonesia, 2(1), 45-53. https://doi.org/10.19184/geosi.v2i1.7524.

Kusumayudha, S. B., Lestari, P., \& Paripurno, E. T. (2018). Eruption characteristic of the sleeping volcano, Sinabung, North Sumatera, Indonesia, and SMS Gateway for Disaster Early Warning System. Indonesian Journal of Geography, 50(1), 70-77. https://doi.org/10.22146/ijg.17574

Latif, A. (2014). Desain sistem informasi geografis pemetaan dan letak kawasan hutan lindung Kabupaten Merauke. Jurnal Ilmiah Mustek Anim Ha, 3(3), 248-266.

Lesmana, I., \& Purnama, A. A. T. (2017). Sistem Informasi Geografis (SIG) dalam pemetaan hasil hutan produksi di Wilayah Kabupaten Kuningan. Buffer Informatika, 1(1). https://doi.org/10.25134/buffer.v1i1.574.

Li, X., Wang, Y., Li, J., \& Lei, B. (2016). Physical and socioeconomic driving forces of landuse and land-cover changes: A case study of Wuhan City, China. Discrete Dynamics in Nature and Society, 2016, 1-11. https://doi.org/10.1155/2016/8061069

Lister, A. J., Andersen, H., Frescino, T., Gatziolis, D., Healey, S., Heath, L. S., Liknes, G. C., McRoberts, R., Moisen, G. G., Nelson, M., Riemann, R., Schleeweis, K., Schroeder, T. A., Westfall, J., \& Wilson, B. T. (2020). Use of Remote sensing data to improve the efficiency of national forest inventories: A case study from the United States National Forest Inventory. Forests, 11(12), 1-41. https://doi.org/10.3390/F11121364.

Luxfiati, A., \& Harudu, L. (2019). Pemetaan distribusi fungsi kawasan hutan di Kabupaten Muna berdasarkan Sistem Informasi Geografis (GIS). Jurnal Penelitian Pendidikan Geografi, 4(4), 151-163. https://doi.org/10.36709/jppg.v4i4.9231. 
Mann, B., \& Saultz, A. (2019). The role of place, geography, and geographic information systems in educational research. AERA Open, 5(3), 1-5. https://doi.org/10.1177/2332858419869340.

Mansaray, L. R., Huang, W., Zhang, D., Huang, J., \& Li, J. (2017). Mapping rice fields in Urban Shanghai, Southeast China, using sentinel-1A and landsat 8 datasets. Remote Sensing, 9(3), 257. https://doi.org/10.3390/RS9030257.

Margono, B. A., Turubanova, S., Zhuravleva, I., Potapov, P., Tyukavina, A., Baccini, A., Goetz, S., \& Hansen, M. C. (2012). Mapping and monitoring deforestation and forest degradation in Sumatra (Indonesia) using landsat time series data sets from 1990 to 2010. Environmental Research Letters, 7(3), 1-16. https://doi.org/10.1088/17489326/7/3/034010.

Masyhuri, W. (2019). Analisa perubahan penggunaan lahan terhadap potensi banjir di Kecamatan Medan Denai. Tunas Geografi, 7(2), 127-132. https://doi.org/10.24114/tgeo.v7i1.7192.

Maula, F. K., Choerunnisa, D. N., \& Akbar, R. (2019). Mapping Informal settlements using geospatial method. IOP Conference Series: Earth and Environmental Science, 385(1), 012035. https://doi.org/10.1088/1755-1315/385/1/012035.

Maulana, A., Jaya, A., \& Sitha, K. (2018). Field characteristic of metamorphic-hosted gold deposit in Sulawesi, Indonesia: An insight into Awak Mas Prospect, South Sulawesi. International Journal of Engineering and Science Application, 4(2), 105-112.

Nguyen, D. B., Clauss, K., Cao, S., Naeimi, V., Kuenzer, C., \& Wagner, W. (2015). Mapping rice seasonality in the Mekong Delta with Multi-Year Envisat ASAR WSM Data. Remote Sensing, 7(12), 15868-15893. https://doi.org/10.3390/RS71215808.

Panek, J., \& Sobotova, L. (2015). Community mapping in urban informal settlements: Examples from Nairobi, Kenya. Electronic Journal of Information Systems in Developing Countries, 68(1), 1-13. https://doi.org/10.1002/j.16814835.2015.tb00487.x.

Perda-Regional Law number 19 year 2013. (2013). Peraturan Daerah Kabupaten Konawe Selatan Nomor 19 Tahun 2013 tentang Rencana Tata Ruang Wilayah Kabupaten Konawe Selatan Tahun 2013-2033. Retrieved from https://peraturan.bpk.go.id/Home/Details/16557.

Rika, H., Susilo, B., \& Nurjani, E. (2016). Geographic information system-based spatial analysis of agricultural land suitability in Yogyakarta. Indonesian Journal of Geography, 47(2), 171-179. https://doi.org/10.22146/IJG.9260.

Saadu, H., Ismail, A., Zulkifli, S. Z., Hashim, A. M., \& Amal, M. N. A. (2021). Associations between anthropogenic activities, forest characteristics and water qualities in the North Selangor Peat Swamp Forest, Selangor, Malaysia. Ecology, Environment and Conservation, 27(1), 1-17. 
Sakarov, O. D. (2019). Analisis kesesuaian lahan untuk lokasi permukiman di Kabupaten Belu Nusa Tenggara Timur. Jurnal Planologi, 16(1), 16-31. https://doi.org/10.30659/jpsa.v16i1.3945.

Sejati, A E, Kasmiati, S., \& Ikhsan, F. A. (2019). The relationship between learning process interactions and student's learning outcomes in environmental sustainability matter geography-social science education subject. IOP Conference Series: Earth and Environmental Science, 282, 012026. https://doi.org/10.1088/1755$1315 / 382 / 1 / 012026$.

Sejati, A.E, Hasan, M., Nursalam, L. O., Harianto, E., \& Deris, D. (2020). Kesesuaian pemetaan penggunaan lahan pemukiman dengan kondisi sebenarnya di Kecamatan Katobu dan Kecamatan Duruka Kabupaten Muna. Tunas Geografi, 9(1), 55-68. https://doi.org/10.24114/tgeo.v9i1.17732.

Setiawan, H., Sudarsono, B., \& Awaluddin, M. (2013). Identifikasi daerah prioritas rehabilitasi lahan kritis kawasan hutan dengan penginderaan jauh dan Sistem Informasi Geografis (Studi Kasus: Kabupaten Pati). Jurnal Geodesi Undip, 2(3), 3141.

Shankar, S. J. (2012). A Study the status of environment education about awareness among, the urban community at Jalgaon District. Scientific Research and Reviews, 1(2), 4959.

Stewart, T. J., \& Janssen, R. (2014). A multiobjective GIS-based land use planning algorithm. Computers, Environment and Urban Systems, 46, 25-34. https://doi.org/10.1016/J.COMPENVURBSYS.2014.04.002.

Suryani, A. I. (2019). Reboisasi/Penghijauan (Peran serta masyarakat dalam penanggulangan bencana longsor). Jurnal Spasial, 4(1), 1-9. https://doi.org/10.22202/js.v4i1.1752.

UU-Law Number 26 year 2007. (2007). Undang-Undang Nomor 26 Tahun 2007 tentang Penataan Ruang. Retrieved from https://peraturan.bpk.go.id/Home/Details/39908/uuno-26-tahun-2007.

Wardhana, W., Widyatmanti, W., Soraya, E., Soeprijadi, D., Larasati, B., Umarhadi, D. A., Hutomo, Y. H. T., Idris, F., \& Wirabuana, P. Y. A. P. (2020). A hybrid approach of remote sensing for mapping vegetation biodiversity in a tropical rainforest. Biodiversitas Journal of Biological Diversity, 21(9), 3946-3953. https://doi.org/10.13057/BIODIV/D210904.

Xu, R. (2021). Mapping rural settlements from landsat and sentinel time series by integrating pixel- and object-based methods. Land, 10(3), 1-18. https://doi.org/10.3390/LAND10030244.

Zhou, H., Xu, F., Dong, J., Yang, Z., Zhao, G., Zhai, J., Qin, Y., \& Xiao, X. (2019). Tracking reforestation in the loess plateau, China after the "Grain for Green" Project through Integrating PALSAR and Landsat Imagery. Remote Sensing, 11(22), 1-22. https://doi.org/10.3390/RS11222685. 
Andri Estining Sejati \& I Gede Purwana Edi Saputra / Geosfera Indonesia 6 (3), 2021, 334-352

Zulfikar, M., Barus, B., \& Sutandi, A. (2013). Pemetaan lahan sawah dan potensinya untuk perlindungan lahan pertanian pangan berkelanjutan di Kabupaten Pasaman Barat, Sumatera Barat. Jurnal Ilmu Tanah Dan Lingkungan, 15(1), 20-28. https://doi.org/10.29244/jitl.15.1.20-28. 